\title{
EFFECT OF FLY ASH ON GEOTECHNICAL PROPERTIES OF LOCAL SOIL-FLY ASH MIXED SAMPLES
}

\author{
Tanaya Deb ${ }^{1}$, Sujit Kumar Pal ${ }^{2}$ \\ ${ }^{1}$ Research Scholar, Civil Engg Dept National Institute of Technology, Agartala, Tripura, India \\ ${ }^{2}$ Assoc. Prof., Civil Engg. Dept., National Institute of Technology, Agartala, Tripura, India, E-mail:
}

\begin{abstract}
The primary fuel of thermal power plants i.e. coal generates significantly huge quantities of solid byproduct as fly ash, bottom ash and pond ash (called fly ash in this study). Fly ash have been collected from Kolaghat Thermal Power Plant, Kolaghat, West Bengal, India. Concerning the major challenges regarding the safe reuse, management and disposal of these wastes an attempt has been made to mix fly ash at 10,15,20,25, and 30\% on the basis of dry weight with local silty-clay soil (Sand $=10.65 \%$, Silt $=52.35 \%$ and Clay = $37.00 \%)$. The local silty-clay soil collected from river bank near to NIT, Agartala, Tripura, India. The study is carried out through large scale tests to simulate field conditions as closely as possible and found to be a very effective means to control the specific gravity $(G)$, liquid limit $(L L)$ and plastic limit $(P L)$, linear shrinkage $(L-S)$, initial void ratio $\left(\mathrm{e}_{\mathrm{i}}\right)$, initial degree of saturation $\left(S_{i}\right)$, maximum dry density $(M D D)$ and optimum moisture content (OMC) at standard Proctor compaction energy, hydraulic conductivity $(k)$, unconfined compressive strength (UCS), free swelling index (FSI), and swelling potential (SP) characteristics. With increase of fly ash contents in the soil-fly ash mixed samples specific gravity, linear shrinkage, plasticity, MDD, $\mathrm{S}_{\mathrm{i}}, U C S$, FSI, and SP have been decreased and OMC, $e_{i}$ increased. Depending on above percentages of fly ash in mixed samples hydraulic conductivity values achieved for soil, soil mixed with 10\% of fly ash (Kolaghat fly ash), and soil mixed with $30 \%$ of fly ash (Kolaghat bottom ash) are 8.60 $\times 10^{-9} \mathrm{~cm} / \mathrm{s}, 3.50 \times 10^{-8} \mathrm{~cm} / \mathrm{s}$, and $1.53 \times 10^{-7} \mathrm{~cm} / \mathrm{s}$ respectively. Up to $30 \%$ of fly ash contents in soil-fly ash mixed sample, this material can be used as liner. 30\% of fly ash contents or above in soil-fly ash mixed sample, this material may be used as land filling and embankments in the field of geotechnical engineering construction.
\end{abstract}

Keywords:- fly ash, silty-clay soil, specific gravity, liquid limit and plastic limit, linear shrinkage, maximum dry density, optimum moisture content, initial void ratio, initial degree of saturation, hydraulic conductivity, unconfined compressive strength, free swelling index, swelling potential.

\section{INTRODUCTION}

In order to cope up with rapid increasing demand of power throughout the world, the production of fly ash is rising hand in hand. Now-a-days it has become a global concern and major challenges to dispose and reuse the fly ash safely, not only for environment but for geotechnical engineers also because - i) disposal of enormous amount of ash involves consumption of huge land and ii) generate the problem of leaching and dusting in wet and dry condition respectively. Therefore, the best way of disposing fly ash is to utilize it with some additives and converting it into a non-hazardous material and apply them in eco-friendly way. Fly ash possesses a wide range of chemical composition and ph values depending on the nature of coal and process of coal burnt (Rollings and Rollings 1996). Kim et al. (2005) concluded that fly ash containing maximum hollow particles of lower apparent specific gravity than most of the solid particles. It is accepted by Kumar (2004) and Prakash and Sridharan (2009) that specific gravity value of pond ash amended soil and coal ashes are less than soil.The affinity of non-plastic fly ash to react (flocculation/agglomeration) with soil and reduces the plasticity of soil-fly ash mixtures as observed by Goh and Tay (1993), Show et al. (2003), and Kalkan and Akbulu (2004). Many previous researchers have explained the reason behind variation in MDD and OMC in soil-fly ash mixed samples on laboratory experiments as revealed by Osinubi (1998), Kalkan and Akbulut (2004), Kumar and Sharma (2004), and Kumar (2004). Effect of pond ash studied by Kumar (2004) on variation of initial void ratio and initial degree of saturation. Due to inclusion of fly ash in additives the hydraulic conductivity gets increased in mixed samples due to flocculation and agglomeration of ash. After sufficient time due to rising up of pozzolanic action hydraulic conductivity decreased a few extents and the same trend observed by Tay and Goh (1991), Ghosh and Subbarao (1998), Osinubi (1998), Porbaha et al. (2000), Show et al. (2003), Kim et al. (2005), Kalkan and Akbulut (2004), Pal and Ghosh (2011). 


\section{MATERIALS}

An investigation has been carried out to evaluate the efficiency in utilization of fly ash in geotechnical field in order to justify safe reuse, management and disposal of fly ash samples. A study of locally available silty clay soil mixed with class F Indian fly ash, bottom ash and pond ash samples have been made in this present study. The fly ash, bottom ash and pond ash are generally called as fly ash in this present study. The materials used are designated as follows:

LS: Silty-clay soil collected from River bank near NIT, Agartala campus, Agartala, Tripura, India;

KF: Fly ash, collected from Kolaghat thermal power station, West Bengal, India;

KB: Bottom ash, from Kolaghat thermal power station, West Bengal, India; and

KP: Pond ash, from Ash pond of Kolaghat thermal power station, West Bengal, India.

The locally available silty-clay soil, Indian fly ash samples and soil-fly ash mixed samples containing fly ash of 10, 15, 20, 25 and $30 \%$ on the basis of dry weight and total nineteen numbers of samples are used for present investigation. Soil-fly ash mixed samples e.g. $75 \mathrm{LS}+25 \mathrm{KF}$ means sample containing $75 \%$ local silty-clay soil and $25 \%$ fly ash by dry weight and 100KP means sample containing $100 \%$ Pond ash by dry weight. All the mix proportions are presented in Table 1.

Table-1: Mixed proportions and mix designations

\begin{tabular}{|ll|}
\hline $\begin{array}{l}\text { Mix } \\
\text { designations }\end{array}$ & Mix Proportions \\
\hline $100 \mathrm{LS}$ & $100 \%$ Local soil \\
$100 \mathrm{KF}$ & $100 \%$ Kolaghat fly ash \\
$100 \mathrm{KP}$ & $100 \%$ Kolaghat pond ash \\
100KB & $100 \%$ Kolaghat bottom ash \\
90LS+10KF & $90 \%$ Local soil+10\% Kolaghat fly ash \\
85LS+15KF & $85 \%$ Local soil+15\% Kolaghat fly ash \\
80LS+20KF & $80 \%$ Local soil+20\% Kolaghat fly ash \\
$75 \mathrm{LS}+25 \mathrm{KF}$ & $75 \%$ Local soil+25\% Kolaghat fly ash \\
$70 \mathrm{LS}+30 \mathrm{KF}$ & $70 \%$ Local soil+30\% Kolaghat fly ash \\
$90 \mathrm{LS}+10 \mathrm{KP}$ & $90 \%$ Local soil+10\% Kolaghat pond ash \\
85LS+15KP & $85 \%$ Local soil+15\% Kolaghat pond ash \\
80LS+20KP & $80 \%$ Local soil+20\% Kolaghat pond ash \\
$75 \mathrm{LS}+25 \mathrm{KP}$ & $75 \%$ Local soil+25\% Kolaghat pond ash \\
$70 \mathrm{LS}+30 \mathrm{KP}$ & $70 \%$ Local soil+30\% Kolaghat pond ash \\
90LS+10KB & $90 \%$ Local soil+10\% Kolaghat bottom ash \\
85LS+15KB & $85 \%$ Local soil+15\% Kolaghat bottom ash \\
80LS +20KB & $80 \%$ Local soil+20\% Kolaghat bottom ash \\
$75 \mathrm{LS}+25 \mathrm{~KB}$ & $75 \%$ Local soil+25\% Kolaghat bottom ash \\
$70 \mathrm{LS}+30 \mathrm{~KB}$ & $70 \%$ Local soil+30\% Kolaghat bottom ash \\
\hline
\end{tabular}

Locally available silty-clay soil is chosen because it is abundantly available in river-beds of this state and containing $10.65 \%$ fine sand, $53.35 \%$ silt, and $37 \%$ clay and having group symbol CL-ML as per USCS. Fly ash used in present study to modify locally available earth material with partial replacement of soil by certain amount of fly ash by weight. The specific gravity, Atterberg's limits, linear shrinkage, maximum dry density and optimum water content, hydraulic conductivity, unconfined compressive strength, and volume change in terms of free swelling index and swelling potential characteristics of locally available soil and fly ash have been studied.

\section{METHODS AND EXPERIMENTAL RESULTS}

The sample preparation and conducting experiments are done according to the ASTM standards as referred under:

$>$ Specific gravity test (D 854-06)

$>$ Grain size distribution analysis (ASTM D 42263(2007))

$>$ Liquid limit and plastic limit tests (ASTM D 431805)

$>$ Linear shrinkage test (ASTM D 423- 1966)

$>$ Standard Proctor compaction test (ASTM D 698-07)

$>$ Hydraulic conductivity test (D 5856-95 (2007)

$>$ Unconfined compressive strength test (ASTM D 2166-06)

$>$ Free swelling index test (ASTM D 4829-11)

$>$ Swelling potential test (ASTM D 4546-08)

\subsection{Linear Shrinkage Test (L-S)}

As per ASTM 423-1966 tests conducted to determine the linear shrinkage of local soil, fly ash and local soil mixed with fly ash specimen. A semi cylindrical mould as its dimensions is specified in code is used to record this parameters. Drying of sample is completed at oven temperature of 105 to $110^{\circ} \mathrm{C}$. The linear shrinkage of the samples shall be calculated from the following formula:

$$
L-S(\%)=\left[1-\frac{\text { length of oven dried specimen }}{\text { init iallength of specimen }}\right] \times 100
$$

In these tests fly-ash samples cannot give any result as they possesses lack of plasticity.

\subsection{Standard Proctor Compaction Test}

Standard Proctor tests (ASTM D698-07) have been carried out to determine the maximum dry density and optimum moisture content for all the nineteen number of the samples. Figs. 9 to 11 shown all the curves of local soil and soil-fly ash mixed samples. The results show that the ash samples attain significantly lower dry unit weight than the soil soil-ash mixtures at relatively lower water content.

\subsection{Hydraulic Conductivity Test}

Falling head permeability is conducted in laboratory as per 5856-95 (2007). Samples compacted in mould at MDD and OMC. It was assumed that the specimen was saturated under water pressure of $1.5 \mathrm{~m}$ height and stationery value reached at 7 days. 


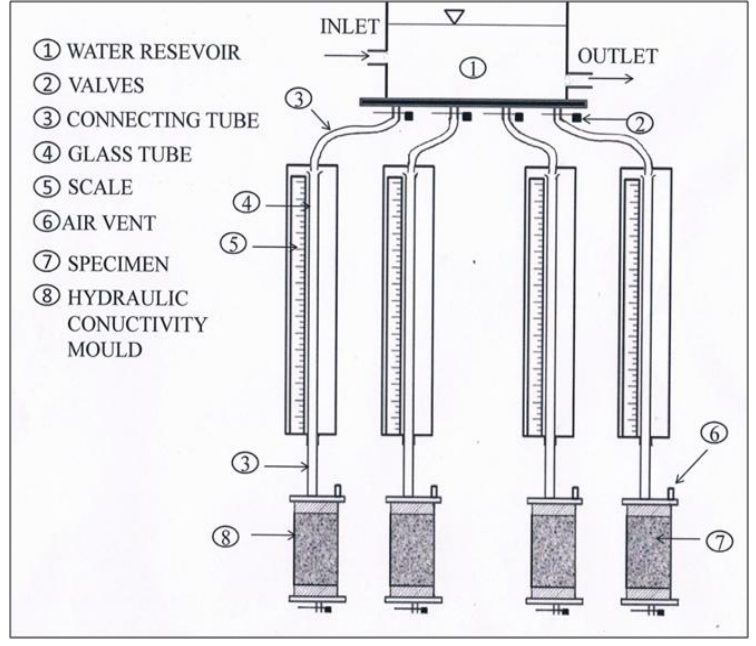

Fig. 1 Falling head hydraulic conductivity test set-up

\subsection{Unconfined Compressive Strength Test}

The compressive strength is conducted in accordance with ASTM D2166-06 and each sample is compacted with predetermined MDD and OMC. At least three specimens are tested for each combination of variables and applied strain rate is $1.5 \mathrm{~mm} / \mathrm{min}$ and $0.5 \mathrm{~mm} / \mathrm{m}$ for local soil, soil-ash mixed samples, and fly ash samples respectively. The unconfined compressive test is performed immediately on fresh samples and on cured samples (stored in moist-proof container) after 7 days. The ash inclusions and curing age have a significant effect on the stress-strain behaviour.

\subsection{Free Swelling Index (FSI)}

As per ASTM D4829-11 tests conducted to determine the free swell index ofall the nineteen samples. FSI is obtained as the ratio of the difference in the final volume of soil in water $\left(\mathrm{V}_{\mathrm{w}}\right)$ and in kerosene $\left(\mathrm{V}_{\mathrm{K}}\right)$ to the final volume in kerosene $\left(\mathrm{V}_{\mathrm{k}}\right)$ and expressed in percentage. In this test fly-ash samples do not respond as they are non-swelling by character. The Free swelling indices of the samples are calculated from the following formula:

$$
\operatorname{FSI}(\%)=\left[\frac{V_{W}-V_{K}}{V_{K}}\right] \mathrm{X} 100
$$

\subsection{Swelling Potential (SP)}

As per ASTM D 4546-08 tests conducted to determine swell potential for each combination of variables as stated previously. The samples are compacted in the consolidation ring at MDD and OMC. The Free swelling potential of the samples are calculated from the following formula
$S P(\%)=\left[\frac{\Delta H}{H}\right] \mathrm{X} 100$

Where, $\Delta H=$ change in thickness of sample, $\mathrm{H}=$ Initial thickness of sample

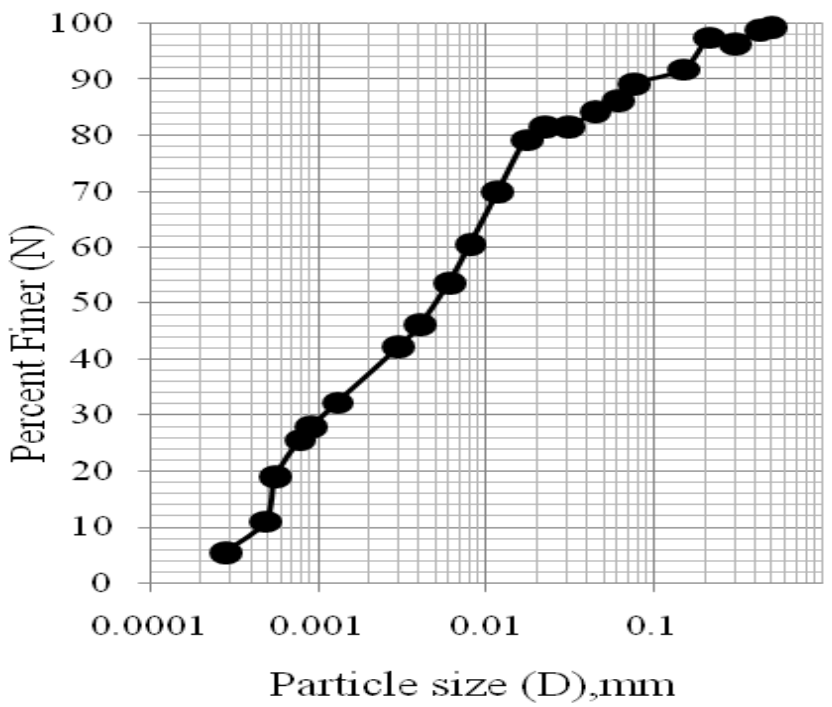

Fig. 2 Percent finer vs. particle size for local silty-clay soil sample

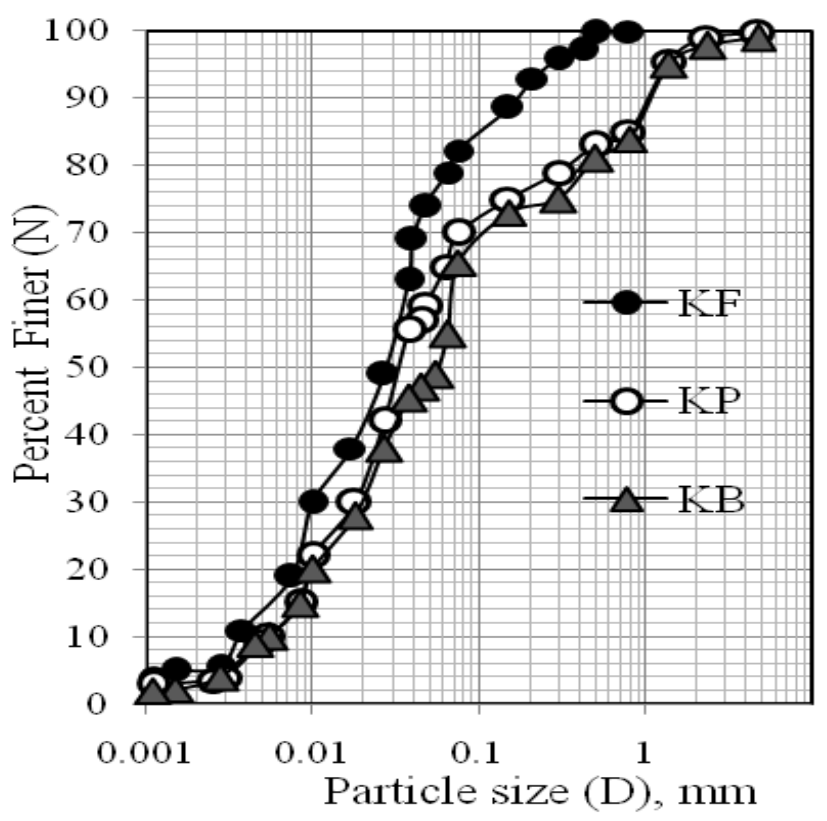

Fig. 3 Percent finer vs. particle size for fly ash samples 


\section{RESULTS AND DISCUSSIONS}

On the basis of the obtained experimental observations, a number of plots which show the variation in geotechnical engineering parameters of local silty-clay soil due to addition of three type fly ash and detailed discussions have been made herein. Effects of fly ash on specific gravity, plasticity index, linear shrinkage, maximum dry density and optimum moisture content, initial void ratio, initial degree of saturation, hydraulic conductivity andunconfined compressive strength of soil-fly ash mixed samples are discussed in this section.

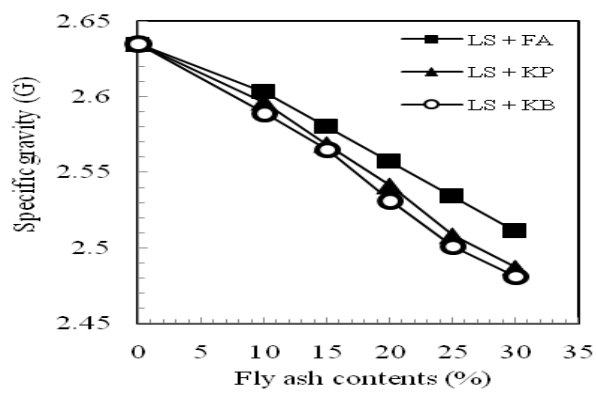

Fig. 4 Specific gravity vs. fly ash content in local soil and soilfly ash mixed samples

\subsection{Effect of Fly Ash on Specific Gravity (G) of Local}

\section{Soil and Soil-Fly Ash Mixed Samples}

The specific gravity $(G)$ values for local silty-clay soil and soil-fly ash mixed samplesare illustrated in Fig. 4. The value of specific gravity of local silty-clay is 2.635. With the increase of fly ash contents in mixed samples, the $\mathrm{G}$ values are decreased. The values of $\mathrm{G}$ are within the range of 2.603 $-2.589,2.580-2.565,2.557-2.531,2.534-2.501$ and $2.511-$ 2.481 for three types of fly ash content in the mix with fly ash of 10, 15, 20, 25 and 30\% respectively.Fly ash particles are hollow, thin walled cenosphere, having low weight than conventional soil, so in mixed samples the overall weight become less. The similar trend was observed for fly ash and bottom ash mixed samples (Kim et al. 2005), for pond ash was amended with locally available soil (Kumar 2004) and for coal ashes as better alternative materials of construction (Prakash and Sridharan (2009).

\subsection{Effect of Fly Ash on Plasticity of Local Soil and}

\section{Soil-Fly Ash Mixed Samples}

The results of the liquid limit (LL), plastic limit (PL), plasticity index (PI) for the local silty-clay soil and soil-fly ash mixed samples are presented in Figs. 5 to 7 respectively. The LL, PL and PI of the local silty-clay soil are 36.9, 22.4 and $14.5 \%$ respectively. With the increase of fly ash contents in mixed samples, the LL and PL are decreased and PI are increased. The values of LL are within the range of 35.90 $35.60,35.60-35.16,34.45-34.20$, 34.15-33.70 and 34.01-
$33.41 \%$ for fly ash content in mix $10,15,20,25$ and $30 \%$ respectively. The values of PL are within the ranges of 23.46 $24.08,23.91-24.47,24.04-25.00,24.25-25.32$ and $24.25-$ $25.41 \%$ forfly ash content in mix 10, 15, 20, 25 and $30 \%$ respectively. The inclusion of non plastic fly ashes in local soil made mixed samples little non plastic. The PI got reduced in the ranges of $12.44-11.52,11.69-10.69,10.41-9.20,9.908 .38$ and $9.85-8.00 \%$ for fly ash content in mix 10, 15, 20, 25 and $30 \%$ respectively. The variation in these arbitrary limits may be attributed to inclusion of non-plastic fly ash and flocculation/agglomeration reaction. The similar trends were commonly observed for MSWIF and as admixtures in stabilization of soft clay (Goh and Tay, 2003), for application of incinerator fly ash and cement to stabilise the marine clay (Show et al. 2003), evaluating potential of limestone dust and coal fly ash to improve some geotechnical properties of clay, for high-calcium and low-calcium class $\mathrm{C}$ fly ash, in order to stabilise an expansive soil and in case of application of silica fume in natural clay liners (Kalkan and Akbulut 2004).

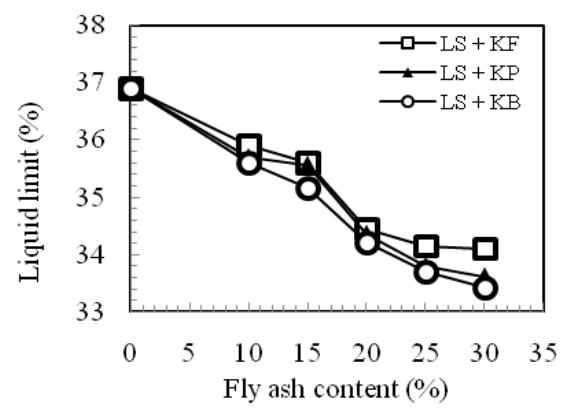

Fig.5 Liquid limit vs. fly ash content in local soil and soil-fly ash mixed samples

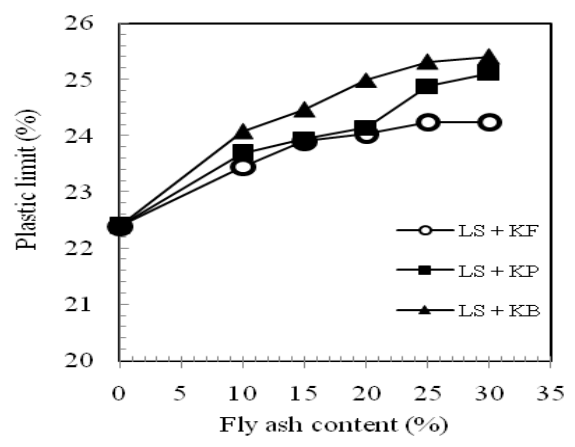

Fig.6 Plastic limit vs. fly ash content in local soil and soil-fly ash mixed samples 


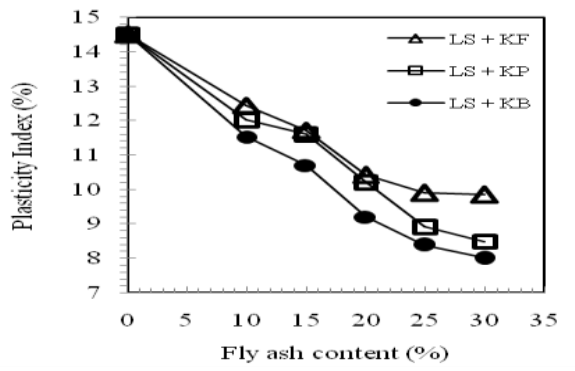

Fig.7 Plasticity index vs. fly ash content in local soil and soilfly ash mixed samples

\subsection{Effect of Fly Ash on linear shrinkage of Local Soil and Soil-Fly Ash Mixed Samples}

The linear shrinkage (L-S) values for the local silty-clay soil and soil-fly ash mixed samples are revealed in Fig. 8. The value of linear shrinkage for the local silty-clay is $10.57 \%$. With the increase of fly ash contents in mixed samples, theshrinkage values are decreased. The ranges of linear shrinkage values are within the range of 9.28-8.80,8.56-7.96, $7.81-6.32,6.81-6.03$ and $5.90-4.88 \%$ for fly ash content in $\operatorname{mix} 10,15,20,25$ and $30 \%$ respectively. The lower the shrinkage, the more flocculation in soil structure occurs in presence of coal fly ash. The addition of non-shrinking and cohesion less fly ashes in local soil decrease the tendency of the mixed samples to shrink. The reductions in linear shrinkage may be due to the ingress of comparative less percentages of water which can be viewed from liquid limit values.

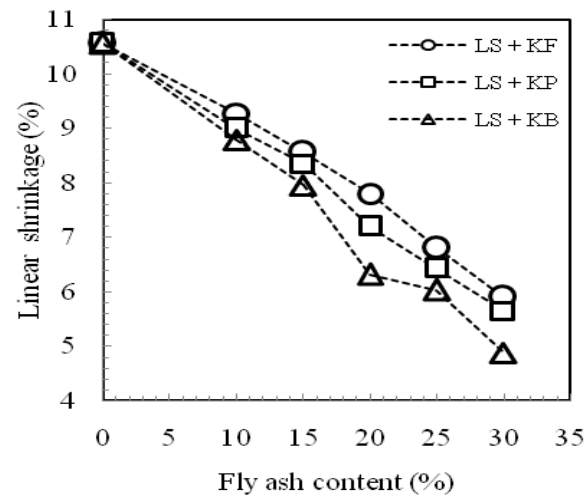

Fig.8 Linear shrinkage vs. fly ash content in local soil and soil-fly ash mixed samples

\subsection{Effect of Fly Ash on Maximum Dry Density (MDD) Andoptimum Moisture Content (OMC) of}

\section{Local Soil and Soil-Fly Ash Mixed Samples}

Compaction effort is one and only parameter that controls the compaction characteristics i.e. dry density and moisture content at optimum state. Moisture content and dry density relation from standard Proctor compaction tests for the local silty-clay soil and soil-fly ash mixed samples are presented in Figs. 9 to 11. The typical values of maximum dry density (MDD) and optimum moisture content (OMC) of local soil and mixed samples depending on the percentages of fly ash content are revealed in Figs. 12 and 13 respectively. The MDD and $\mathrm{OMC}$ of local silty-clay soil are $16.20 \mathrm{kN} / \mathrm{m}^{3}$ and $18.91 \%$ respectively. The MDD and OMC values of fly ash samples are within the range of $11.00-12.30 \mathrm{kN} / \mathrm{m}^{3}$ and $34.00-25.32 \%$ respectively. The values of MDD are within the range of $15.71-15.58,15.51-15.32,15.27-15.06,15.1244 .80$ and $14.80-14.53 \mathrm{kN} / \mathrm{m}^{3}$ and the corresponding values of OMC are within the range of 19.77-19.92, 20.00-20.47, 20.56-20.91, $20.68-21.33$ and $21.37-21.82 \%$ for fly ash content in mix 10 , $15,20,25$ and $30 \%$ respectively. The inclusion of low weight and coarser fly ashes in local soil can make the mixed samples comparatively coarser and decrease the overall weight. The significance of these changes depends upon the amount of ash added and the chemical composition of the clay minerals and ash. The decrease resulted from the flocculation and agglomeration of clay particles in presence of sufficient water leading to increase in voids and corresponding decreases in dry densities. The reason for the increasing OMC may be attributable to the affinity of the soil-fly ash mixed samples for more water to complete the cation exchange reaction and with application of compaction effort the voids are occupied by more water. The Similar trend was observed by Osinubi (1998) in case of compaction delays on lime-treated lateritic soil with compaction delay and no compaction delays. Kalkan and Akbulu (2004) were also observed similar result in application of silica fume for natural clay liners.The results show more conformity with the present trend when Kumar and Sharma (2004) evaluated the efficiency of fly ash as an additive in improving the engineering characteristics of expansive soils, Kumar (2004) studied compaction characteristics of pond ash amended locally available soil, and Brook et al. (2011)reported stabilizing problem soils stabilized by coal fly ash and limestone dust.

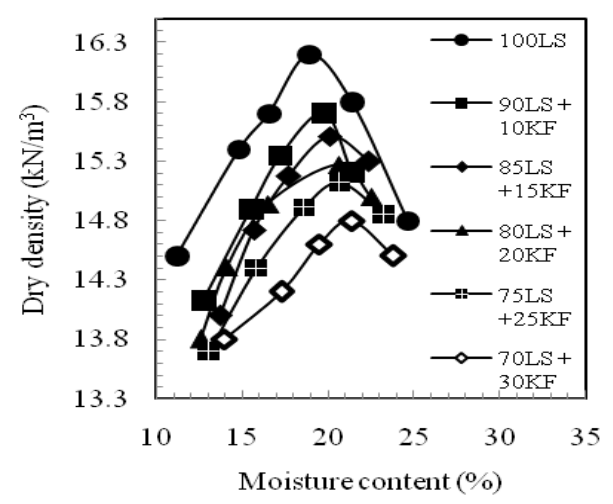

Fig.9 Dry density vs. moisture content in local soil and soil-fly ash mixed samples 


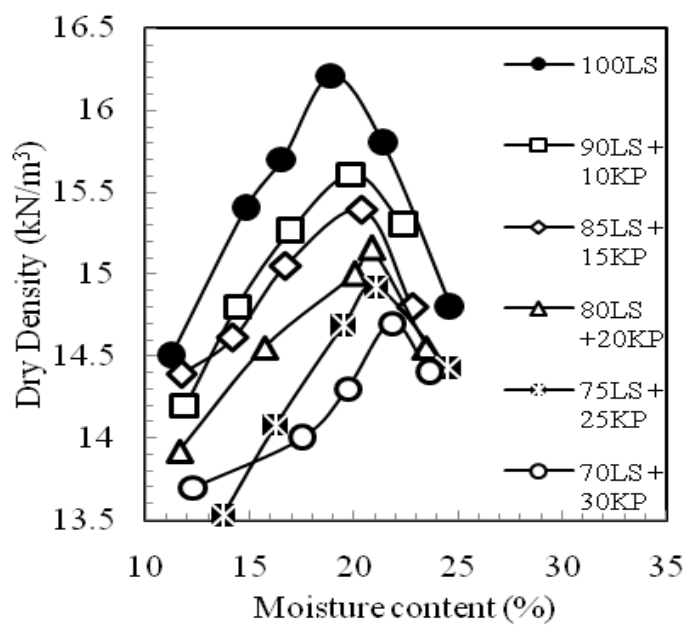

Fig.10 Dry density vs. moisture content in local soil and soilfly ash mixed samples

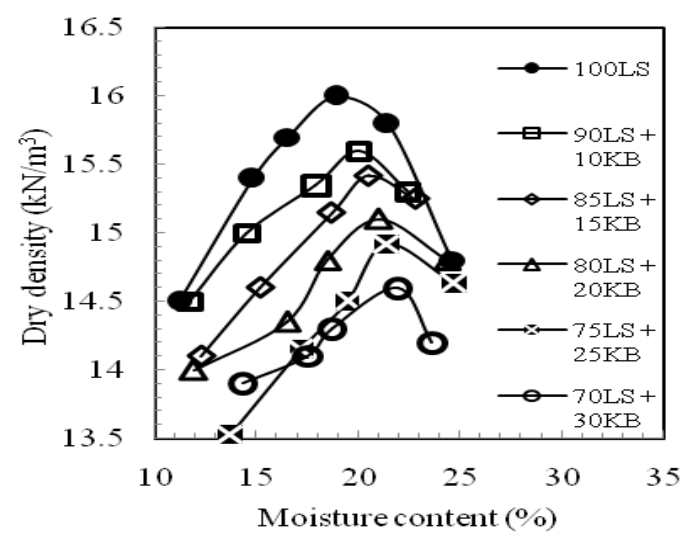

Fig.11 Dry density vs. moisture content in local soil and soilbottom ash mixed samples

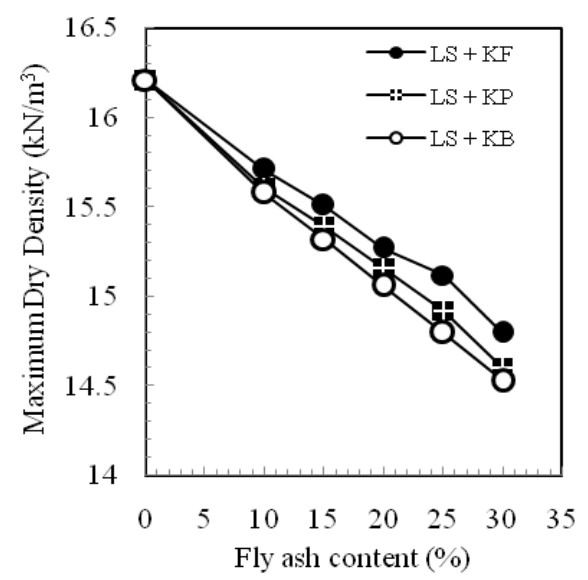

Fig.12 Maximum dry density (MDD) vs. fly ash content in local soil and soil-fly ash mixed samples

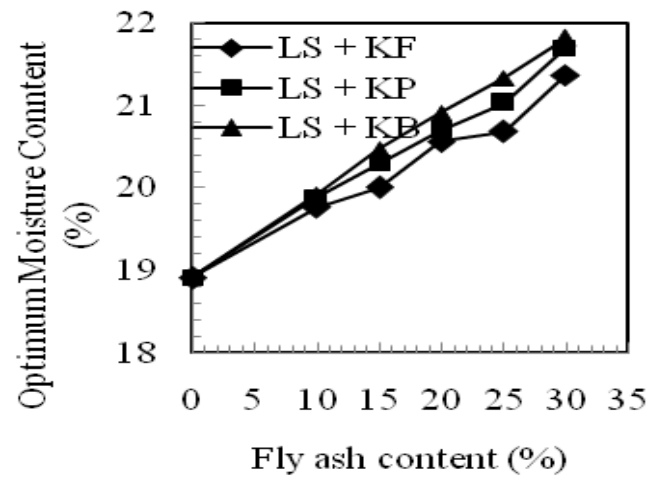

Fig.13 Optimum moisture content (OMC) vs. fly ash content in local soil and soil-fly ash mixed samples

\subsection{Effect of Fly Ash on Initial Void Ratio ( $\left.e_{i}\right)$ of Local Soil and Soil-Fly Ash Mixed Samples}

The values of initial void ratio $\left(e_{i}\right)$ for the local silty-clay soil and soil-fly ash mixed samples are summarized in Fig. 14. The initial void ratio of local silty-clay soil is 0.627 . With the increase of fly ash contents in mixed samples, the $e_{i}$ values are increased. The values of $e_{i}$ are within the ranges of $0.657-$ $0.661,0.663-0.674,0.675-0.681,0.676-0.691$ and $0.696-$ 0.707 for fly ash content in mixed samples at $10,15,20,25$ and $30 \%$ respectively. The increase in voids resulted from the flocculation and agglomeration of clay particles in presence of sufficient water. The Similar trend was observed by Kumar (2004) in study of compaction characteristics of pond ash amended locally available soil when calculated from $G$ and MDD values.

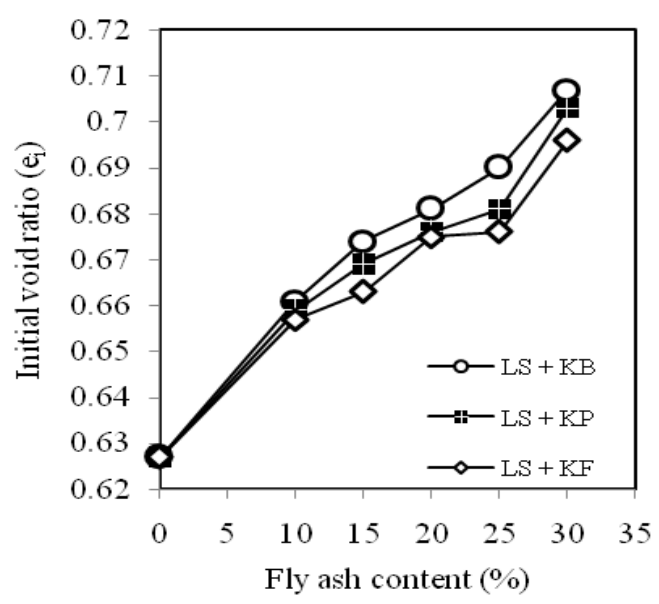

Fig.14 Initial void ratio vs. fly ash content in local soil and soil-fly ash mixed samples 


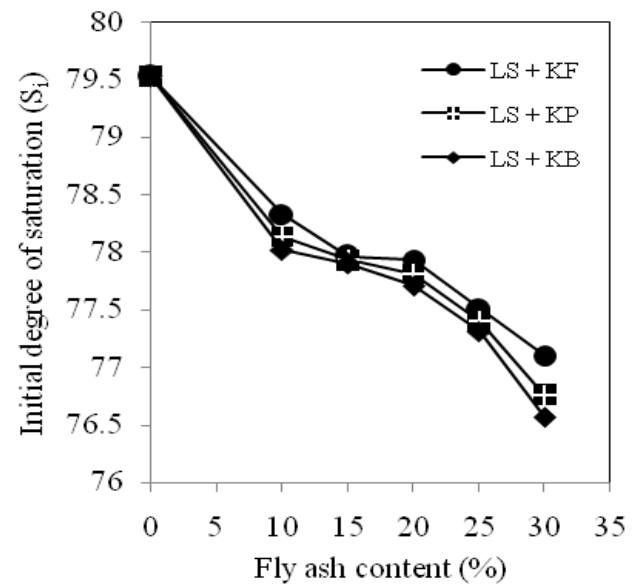

Fig.15 Initial degree of saturation vs. fly ash content in local soil and soil-fly ash mixedsamples

\subsection{Effect of Fly Ash on Initial Degree of Saturation}

\section{$\left(\mathrm{S}_{\mathrm{i}}\right)$ of Local Soil and Soil-Fly Ash Mixed Samples}

The values of initial degree of saturation $\left(\mathrm{S}_{\mathrm{i}}\right)$ for the local silty-clay soil and soil-fly ash mixed samples are shown in Fig. 15. The initial degree of saturation of local silty clay soil is $79.525 \%$. With the increase of fly ash contents in mixed samples, the $S_{i}$ values are decreased. The values of $S_{i}$ are within the range of 78.33-78.02, 77.96-78.90, 77.93-77.71, $77.51-77.31$ and $77.10-76.57 \%$ for fly ash content of 10,15 , 20,25 and $30 \%$ respectively, in the mix. The decrease resulted from the flocculation and agglomeration of clay particles in presence of sufficient water leading to increase in voids and the volume of voids cannot be occupied by sufficient volume of water. The Similar trend was observed by Kumar (2004) in study of compaction characteristics of pond ash amended locally available soil when $S_{i}$ values are calculated from available values of $\mathrm{e}_{\mathrm{i}}, \mathrm{G}$ and $\mathrm{OMC}$.

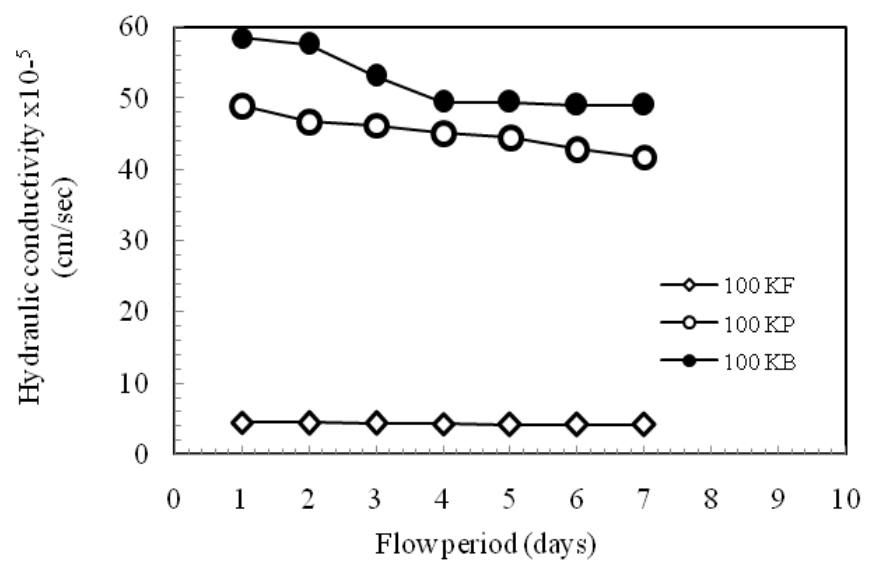

Fig.16 Hydraulic conductivity vs. flow period for fly ash samples

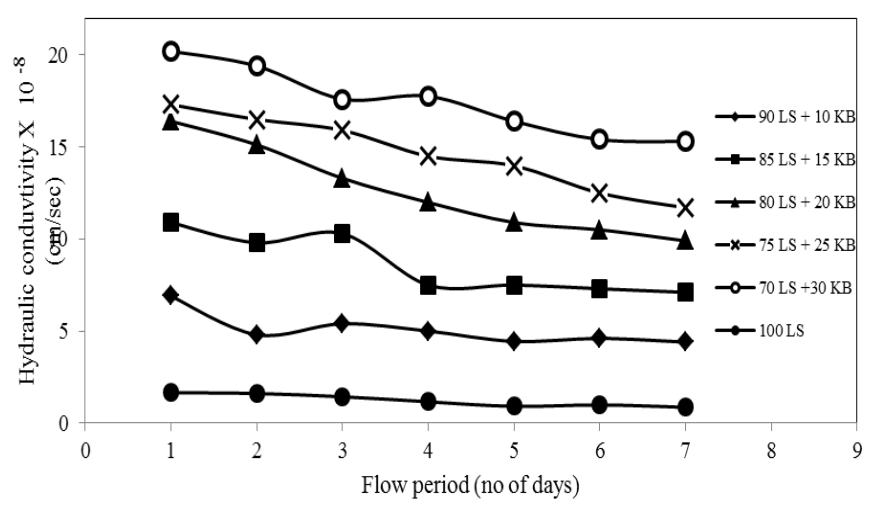

Fig.17 Hydraulic conductivity vs. flow period for local soil and soil-bottom ash mixed samples

\subsection{Effect of Fly Ash on Hydraulic Conductivity (k) of Local Soil and Soil-Fly Ash Mixed Samples}

The gradual decreasing trend with some fluctuations in hydraulic conductivity $(\mathrm{k})$ valuesfor seven days in fly ash samples, soil and soil-bottom ash mixed samples are presented in Figs. 16 and 17 respectively. The hydraulic conductivity for the local silty-clay soil is $8.6 \times 10^{-9} \mathrm{~cm} / \mathrm{sec}$. With the increase of fly ash contents in mixed samples, the $\mathrm{k}$ values are increased. The hydraulic conductivity values are within the range of $3.5-4.4 \times 10^{-8}, 5.9-7.1 \times 10^{-8}, 8.3-9.9 \times 10^{-8}$ and $13.3-$ $15.3 \times 10^{-8} \mathrm{~cm} / \mathrm{sec}$ with percentages of fly ash $10,15,20,25$ and $30 \%$ respectively, in the mix as presented in Fig. 18. The addition of free draining and coarser fly ashes in local soil can make the mixed samples comparatively coarser and offer the passage for flow of water. Tay and Goh (1991) found that in presence of $10 \%$ and $20 \%$ incinerator fly ash with soft marine clay increase the permeability upto seven days. After sufficient time the formation of cementitious and pozzolanic gels, filling the voids of flocculated soil particles. Previous researchers like, Ghosh and Subbarao (1998) in stabilization of a low lime fly ash with lime and gypsum, Osinubi (1998) in Hekinan and Matsushima fly ash for direct falling head permeability, and Porbaha et al. (2000) in conducting indirect calculation from consolidation observed similar trend. Similar trend was also reported by Show et al. (2003) in compacted fly and bottom ash mixtures with increasing fly ash content, Kim et al. (2005) in high volume fly ash cement paste composite formed of various combinations of fly ash, cement, lime, silica fume, and chemical admixtures, Kalkan and Akbulut (2004) in application of silica fume for natural clay liners, and Pal and Ghosh (2011) in nine numbers of class F Indian fly ash. 


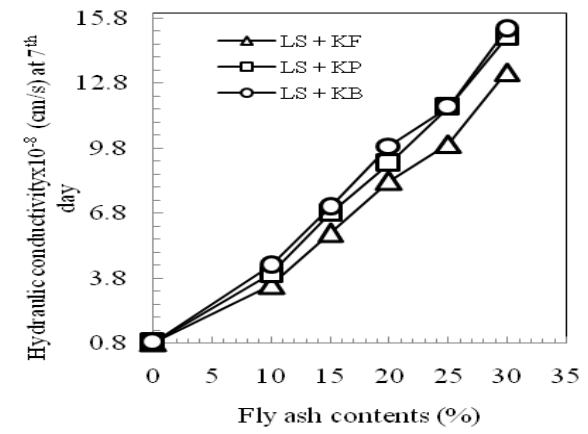

Fig.18 Hydraulic conductivity vs. fly ash content at 7 days in local soil and soil-fly ash mixed samples

\subsection{Effect of Fly Ash on Unconfined Compressive} Strength (UCS) of Local Soil and Soil-Fly Ash Mixed

\section{Samples}

The unconfined compressive strength values for the local silty-clay soil and soil-fly ash mixed samples on immediate and 7th day test samples are illustrated in Figs.19 and 20 respectively. The $1^{\text {st }}$ day value of unconfined compressive strength for the local silty-clay soil is $325.00 \mathrm{kPa}$ and at $7^{\text {th }}$ day it becomes $340.00 \mathrm{kPa}$. With the increase of fly ash contents in mixed samples, the UCS values are decreased. The $1^{\text {st }}$ day value of UCS are within the ranges of 210.66-193.88, 200.75-184.00, 191.30-175.73, 181.35-165.69 and 171.00$156.00 \mathrm{kPa}$ with percentages of fly ash content $10,15,20,25$ and $30 \%$ respectively, in the mix. The inclusion of cohesion less and coarser fly ash in local soil can make the mixed samples comparatively coarser and decrease the unconfined compressive strength. The decrease in strength may be due to the flocculation and agglomeration of clay particles in presence of sufficient water leading to decreases in dry densities and corresponding increase in voids. The porosity is related to lack of points of contacts among the soil particles. The similar trend was observed by Consoli et al. (2011) when lime and fly ash mixed with local soil. The ranges of compressive strength values at $7^{\text {th }}$ day are $253.13-225.19$, 239.13-216.07, 222.60-210.56, 208.89-192.52 and 192.2$175.05 \mathrm{kPa}$ for fly ash content of 10,15, 20, 25 and $30 \%$ respectively, in the mix.It implies that with curing period the strengths get increased due to pozzolanic action of fly ash. The similar trend was observed by Tay and Goh (1991) for incinerator residue mixed with soft soil and Goh and Tay (1993) for municipal solid waste incinerated fly ash-cement and lime-stabilized samples. Osinubi (1998) for the strength improvement of the lime-treated lateritic soil, Das and Yudhbir (2005) for finding geotechnical characterisation of some Indian low calcium-fly ash, and Brooks et al. (2011) for two lean clay stabilized with fly ash and limestone dust also observed similar trend in their studies.

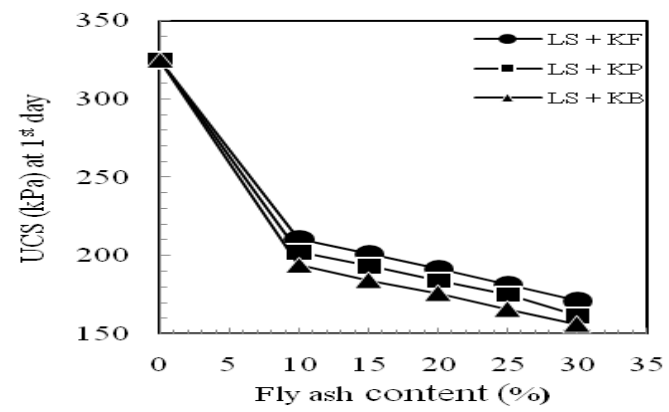

Fig.19 UCS vs. fly ash content at $1^{\text {st }}$ day

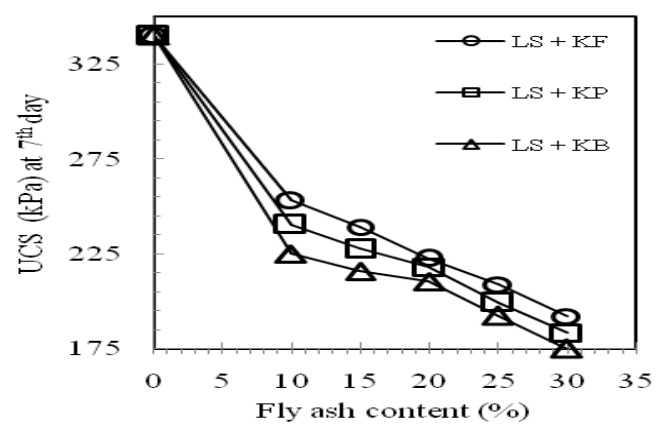

Fig. 20 UCS vs. fly ash content at $7^{\text {th }}$ day

\subsection{Effect of Fly Ash on Free Swelling Index (FSI) of}

\section{Local Soil and Soil-Fly Ash Mixed Samples}

The free swelling index (FSI) valuesfor the local silty-clay soil and soil-fly ash mixed samples are revealed from Table 2.The value free swelling index of local local silty-clay soil is $17.00 \%$. With the increase of fly ash contents in mixed samples, thefree swelling index values are decreased gradually. The FSI values reduced to within the range of 11.4$10.5,8.84-7.91,6.11-5.10$ and $4.05-2.70 \%$ with percentage of fly ash 10, 15, 20, 25 and $30 \%$ respectively, in the mix. At the presence of $30 \%$ ash content the reductions in FSI values further reduces and become negligible. The addition of non swelling and cohesion less fly ashes in local soil decrease the swelling tendency of the mixed samples. The reductions in FSI values may be due to the deflocculating effect, which prevent the ingress of water among clay particles as clay loses the affinity towards the water and their surface area get reduced. The Similar trend was observed by Kumar and Sharma $(2004,2007)$ for improving the engineering characteristics of expansive soils by fly ash.

Table-2: Free swelling index (FSI) and swelling potential (SP) of local soil, fly ash and soil-fly ash mixed samples

\begin{tabular}{|lll|}
\hline Sample & F S I (\%) & SP (\%) \\
\hline $100 \mathrm{LS}$ & 17.00 & 02.20 \\
$100 \mathrm{KF}$ & Non-swelling & Non-swelling \\
$100 \mathrm{KP}$ & Non-swelling & Non-swelling \\
\hline
\end{tabular}




\begin{tabular}{|lll|} 
100KB & Non-swelling & Non-swelling \\
90LS + 10KF & 11.40 & 1.40 \\
85LS + 15KF & 08.84 & 0.90 \\
80LS + 20KF & 06.11 & Negligible \\
75LS + 25KF & 04.05 & Negligible \\
70LS + 30KF & Negligible & Negligible \\
90LS + 10KP & 10.50 & 01.03 \\
85LS + 15KP & 07.91 & 00.71 \\
80LS + 20KP & 05.10 & Negligible \\
75LS + 25KP & 02.70 & Negligible \\
70LS + 30KP & Negligible & Negligible \\
90LS + 10KB & 10.80 & 01.13 \\
85LS + 15KB & 08.16 & 00.83 \\
80LS + 20KB & 05.50 & Negligible \\
75LS + 25KB & 03.91 & Negligible \\
70LS + 30KB & Negligible & Negligible \\
\hline
\end{tabular}

\subsection{Effect of Fly Ash on Swelling Potential (SP) of}

\section{Local Soil and Soil-Fly Ash Mixed Samples}

The swelling potential (SP) values for the local silty-clay soil and soil-fly ash mixed samples are revealed from Table 2.The value free swelling index of original local silty-clay soil is $2.2 \%$. With the increase of fly ash contents in mixed samples, the swelling potential values are decreased gradually. The SP values reduced in the range of $1.40-1.03 \%$ and $0.90-0.71 \%$ in mixed samples for fly ash content of 10 and $15 \%$ respectively. Upto $30 \%$ of fly ash contents in the mix, the reductions in SP values are more and became negligible. The addition of non swelling and cohesion less fly ashes in local soil decrease the tendency of the mixed samples to swell. The reductions in SP values may be due to the deflocculating effect, which results in clay particles reduced by surface area, get lose affinity towards the water and consequently ingress of water among the clay particles is prevented. The Similar trend was observed by Kumar and Sharma (2004) for improving the engineering characteristics of expansive soils in presence of coal fly ash, and Brooks et al. (2011) to stabilize two types of lean clay by limestone dust and coal fly ash.

\section{CONCLUSIONS}

The following conclusions are made based on the above results and discussions:

- In general, decrease in values of specific gravity, plasticity index and linear shrinkage in the soil-fly ash mix samples irrespective of fly ash type.

- With the increase of ash content in the soil-ash mix samples, MDD decreases and OMC increases irrespective of ash type.

- With the increase of ash content in the soil-ash mix, initial void ratio increases, and degree of saturation decreases irrespective of ash type.

- In general, hydraulic conductivity values increases with higher percentage of fly ash content in the mix and maximum value attain $1 \times 10^{-7} \mathrm{~cm} / \mathrm{sec}$. Local silty clay soil-fly ash mixed samples with fly ash content of 10,15,20, 25 and $30 \%$ can be used as liner material.

- With higher fly ash content in the mix UCS values gradually decrease irrespective of ash type, but as a whole the $7^{\text {th }}$ day UCS values are showing increasing trend than $1^{\text {st }}$ day values.

- As the ash content increases the swelling potential and free swelling index, both decreases.

- $30 \%$ of fly ash contents or above in local silty clay soil-fly ash mixed sample, this material may be used as land filling and embankments in the field of geotechnical engineering construction.

\section{REFERENCES}

[1]. Brooks, R., Udoeyo, F. F., and Takkalapelli, K. V. "Geotechnical properties of problem soils stabilized with fly ash and limestone dust in philadelphia" J. Mater. Civ. Engg., ASCE, Vol. 23, no. 5, pp.711-716, May 2011.

[2]. Consoli, N. C., Rosa, A. D., and Saldanha. R. B. "Variables governing strength of compacted soil-fly ash-lime mixtures" J. Mater. Civ. Engg., ASCE, Vol. 23, no. 4, pp. 432440, April 2011.

[3]. Ghosh, A., and Subbarao, C."Hydraulic conductivity and leachate characteristics of stabilized fly ash" J. Environ. Engg, ASCE, Vol.124, no.9, pp. 812-820, September 1998.

[4]. Goh, A. T. C., and Tay, J. H. "Municipal solid-waste incinerator fly ash for geotechnical applications." J. Geotech. Engg, ASCE, New York, N.Y., 119, no. 5, pp. 5-811, May 1993.

[5]. Kalkan, E., and Akbulut, S. "The positive effects of silica fume on the permeability, swelling pressure and compressive strength of natural clay liners" Eng. Geol. Elsevier, 73.pp.145-156, January 2004.

[6]. Kim, B., Prezzi, M., and Salgado, R. "Geotechnical properties of fly and bottom ash mixtures for use in highway embankments" J. Geotech. Geoenviron. Engg., ASCE, Vol. 131, no. 7, pp. 914-924, July 2005.

[7]. (a) Kumar, B. R. P., and Sharma, R. S "Effect of fly ash on engineering properties of expansive soils" J. Geotech. Geoenviron. Engg., ASCE, Vol. 130, no. 7, pp. 764-767, July 2004,

[8]. (b) Kumar, B. R. P., and Sharma, R. S. "Volume change behavior of fly ash-stabilized clays" J. Mater. Civ. Engg., ASCE, Vol. 19, no. 1, pp. 67-74, January 2007.

[9]. Kumar, V. "Compaction and permeability study of pond ash amended with locally available soil and hardening agent" Journal of The Institution of Engineers (India), vol. 85, pp. 3135, July 2004.

[10]. Osinubi, K. J. "Permeability of lime-treated lateritic soil" J. Trans. Engg., ASCE, Vol. 124, no. 5,pp. 465- 469, April 1998.

[11]. Osinubi, K. J., and Nwaiwu, C. M. O. "Hydraulic conductivity of compacted lateritic soil" J. Geotech. Geoenviron. Engg, ASCE, Vol. 131, no.8, pp.1034-1041, August 2005 
[12]. Pal, S.K., and Ghosh, A. "Compaction and hydraulic conductivity characteristics of Indian Fly ashes" Proceedings of Indian Geotechnical Conference, 2011, Paper No.L-326, Kochi, December 2011.

[13]. Porbaha, A., Pradhan, T. B. S. and Yamane, N. "Time effect on shear strength and permeability of fly ash" J. Energy Engg., ASCE, Vol. 126, no.1, pp.15-31, April 2000.

[14]. Prakash, K., and Sridharan, A. "Beneficial properties of coal ashes and effective solid waste management" Practice Periodical of Hazardous, Toxic, and Radioactive Waste Management, ASCE, Vol.13 no. 4 no., pp 239-248, October 2009.

[15]. Rollings, M. P., and Rollings, R. S. "Geotechnical materials in construction", McGraw-Hill, New York, 1996

[16]. Show, K. Y., Tay, J.H., and Goh, A. T. C. "Reuse of incinerator fly ash in soft soil stabilization" J. Mater. Civ. Engg., ASCE, Vol. 15. (4) pp. 335-343, August 2003.

[17]. Tay, J.H. and Goh, A. T. C. "Engineering properties of incinerator residue" J. Environ. Engg, ASCE,Vol. 117, no.2, pp. 224-235, April 1991.

\section{BIOGRAPHIES:}

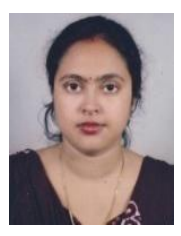

Tanaya Deb presently is a Research Scholar in Civil Engineering Dept., NIT, Agartala, Tripura, INDIA. Completed BE (Civil and Transportation Engg.) with Gold medal in 2010 and M. Tech (Geotechnical Engg.) in 2012 from NIT, Agartala. She has publications in Journals and conferences like, EJGE, IGC etc. Her present research work is analysis on pile foundation.

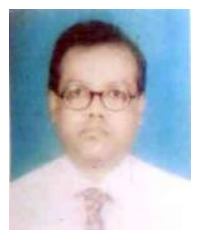

Dr. Sujit Kumar Pal is presently working as Associate Professor in Civil Engg., NIT, Agartala, Tripura, INDIA. Completed BE (Civil Engg.) from REC, Surathkal, Karnataka, INDIA (Presently, NIT, Surathkal) in 1986 and M. Tech (Soil Mech. \& Foundation Engg.) from IIT, Khragpur, West Bengal, INDIA in January, 1994. He has completed his Ph.D (Engg.) from Bengal Engineering and Science University, Shibpur, West Bengal, INDIA (Presently, Indian Institute of Engineering Science and Technology, Shibpur) in January, 2010. He has a wide range of publications in national and international Journals and conferences like, ASCE, SPRINGER, EJGE, IGC etc. His present research areas are soil characterization, soil dynamics, ground improvement, shallow and deep foundations and soilstructure interaction. 